\title{
Biomass and Carbon Content Allocation of Six-year-old Anisoptera Costata Korth., nd Dalbergia Cochinchinensis Pierre, Plantations in Lao PDR
}

\author{
Chanhsamone Phongoudome ${ }^{1 *}$, Don Koo Lee ${ }^{2}$, Silavanh Sawathvong ${ }^{3}$, \\ Marilyn S. Combalicer ${ }^{4}$, and Wai Mun $\mathrm{Ho}^{5}$
}

${ }^{1}$ Ph.D Candidate, Silviculture and Restoration Ecology Laboratory, Department of Forest Sciences, College of Agriculture and Life Sciences, Seoul National University, Seoul, 151-921, Korea

${ }^{1}$ Professor, Silviculture and Restoration Ecology Laboratory, Department of Forest Sciences, College of Agriculture and Life Sciences, Seoul National University, Seoul, 151-921, Korea

${ }^{3}$ Department of Forestry, Ministry of Agriculture and Forestry, Lao PDR

4Professor, College of Forestry, Nueva Vizcaya State University,

Bayombong, Nueva Vizcaya 3700, Philippines

${ }^{5}$ Researcher, Forest Research Institute Malaysia,

52109 Kepong, Selangor Malaysia

\begin{abstract}
The objective of our study was to examine the biomass and carbon contents (including soil) of two six-year-old native species, Anisoptera costata and Dalbergia cochinchinensis. Forest plantation is an important strategy to restore degraded forest ecosystem not only for increasing timber supply, but also for socio-economics, environmental and biodiversity purposes. In addition, forest plantations helps to increase the biomass density and carbon content besides improving soil conditions. Increasing forest plantations can help reduce carbon dioxide emission in the atmosphere. In this study, the biomass and carbon contents of trees and soil in plantations were determined. The two species $A$. costata and $D$. cochinchinensis, both planted June 2002, were selected for this study. Stem, branch, leaf and root components were measured to obtain biomass and carbon contents. Results of the study showed that a total biomass of 5.63 $\pm 1.23 \mathrm{t} \mathrm{ha}^{-1}$ and $5.42 \pm 0.94 \mathrm{t} \mathrm{ha}^{1}{ }^{1}$ were accumulated in A. costata and D. cochinchinensis, respectively. Meanwhile, the carbon contents recorded were $2.58 \pm 0.45 \mathrm{t} \mathrm{ha}^{-1}$ and $2.50 \pm 0.32 \mathrm{t} \mathrm{ha-}^{1}$ in $A$. costata and D. cochinchinensis, respectively. However, soil organic carbon content was found to be higher in $D$. cochinchinensis $0.68 \pm 0.05 \%$ than $A$. costata 0.57 $\pm 0.02 \%$. These data will be useful in designing forest plantation for long term management using native tree species.
\end{abstract}

Keywords: biomass, carbon content, fresh weight, growth performance, soil organic carbon

\section{Introduction}

According to FAO, the world's forest plantation accounted for less than $7 \%$ or 264 million ha of total forest areas, in which $78 \%$ are productive and $22 \%$ are protective. Most of this was established through afforestation, three-quarter of all planted forest consist of native species, while one-quarter comprises introduced species. It is estimated that the world's forests store 289 gigatonnes (Gt) of carbon (C) in their biomass alone and decreased $0.5 \mathrm{Gt}$ annually during the period 2005-2010 (FAO, 2010). The total C storage in forest plantations nowadays is approximately $11.8 \mathrm{Gt}$ with an increase of $0.178 \mathrm{Gt} \mathrm{yr}^{-1}$, tropical forests that spread over 13.76 million $\mathrm{km}^{2}$ worldwide account for $60 \%$ of the global forest (FAO, 2010; Dutca et al., 2009) and plays a key role in global C cycle both in terms of $C$ flux and volume of $C$ stored (Baishya et al., 2009). The estimations made by Houghton and Goodale (2004) regarding C storage in plantations during the 1990s indicated a global level rate of $0.19 \mathrm{Gt} \mathrm{yr}^{-1}$. They also estimated the annual $\mathrm{C}$ storage rate in tropical plantations $\left(0.11 \mathrm{Gt} \mathrm{yr}^{-1}\right)$, and in the temperate and boreal plantations $\left(0.081 \mathrm{Gt} \mathrm{yr}^{1}\right)$. Carbon management in forests is a global concern to mitigate the increased concentration of green-house gases in the atmosphere (Singh and Lodhiyal, 2009). At the global level, forest plantations represent less than $10 \%$ of deforested areas and tree planting currently compensates about $0.3 \%$ of the carbon released by deforestation (Montagnini and Porras, 1998; Dutca et al., 2009). The establishment of plantations has been proposed as a tool for forest restoration of degraded lands because of their effects on vegetation structure, microclimate and soil (Affendy et al., 2009). Plantations of multi-purpose tree species can play an important role in restoring productivity, ecosystem stability, and biological diversity of degraded tropical lands (Parrotta, 1992; Piotto et al., 2004). In addition, reforestation is being considered as a mitigation option to reduce the increase in atmospheric carbon dioxide and predicted climate change. Forestry-based $\mathrm{C}$ storage projects are thus being introduced in many tropical countries but assessment of $\mathrm{C}$ storage potentials is made difficult by a lack of species-level information (Kraenzel et al., 2003). The ability of these plantations to sequester $\mathrm{C}$ has received renewed interest since $\mathrm{C}$ sequestration projects in developing nations could receive investments from companies and governments wishing to offset their emission of green-house gases through the Kyoto Protocol's Clean Development Mechanism (CDM) (Losi et al., 2003). There are two common methods being used to estimate biomass and $\mathrm{C}$ content for both plantation and natural forest: volume equation and regression equation (Francis, 2000; Losi et al., 2003). The role of soil in the global $\mathrm{C}$ cycle has also been receiving greater scientific attention (Lugo and Brown, 1993).

In Lao PDRs, there were 306,000 ha of forest plantation up to 2009, in which more than $50 \%$ was rubber (DoF, 2009), but assessment of the $\mathrm{C}$ potentials has not been done. The government aims to increase the national forest cover of up to $70 \%$ of total land area by the year 2020 through natural regeneration in more than six million ha and another 0.5 million ha by plantations especially in degraded forests including fallow forests and logged-over forests as stipulated in the Forestry Strategy 2020 (MAF, 2005). The objective of this study was to examine the allocation of biomass and $\mathrm{C}$ contents (including soil) of two six-year-old native species, A. ostata and D. cochinchinensis.

\section{Materials and Methods}

\section{Site description}

The study was conducted from February to March 2008 at the Forestry Research Centre, National Agriculture and Forestry Research Institute, Lao PDR. It is located in the north of Vientiane Capital City (between $18^{\circ} 15^{\prime} 32^{\prime \prime} \mathrm{N}$ latitude and $102^{\circ} 26^{\prime} 59^{\prime \prime} \mathrm{E}$ 
longitude), with an altitude of $195 \mathrm{~m}$ above sea level (a.s.l) (Figure 1). Rainfall at the site averaged $1990 \mathrm{~mm}$ per year (2000-2008), and was moderately seasonal in distribution. longitude), with an altitude of $195 \mathrm{~m}$ above sea level (a.s.l) (Figure 1). Rainfall at the site averaged $1990 \mathrm{~mm}$ per year (2000-2008). and was moderately seasonal in distribution. Average air temperature ranges from $23.50 \mathrm{C}$ in December to $30.5 \mathrm{oC}$ in May. The relative humidity ranges from $69 \%$ in February to $84 \%$ in August. Soil texture is as follows: sand $88.5 \%$, silt $4.8 \%$ and clay $6.7 \%$. The soil is welldrained and considerably acidic with $\mathrm{pH}$ between 4.36 and -5.00 . The plantation density is 1111 tree/ha with tree spacing of $3 \mathrm{~m} \mathrm{x}$ $3 \mathrm{~m}$.

\section{Data collection}

In order to estimate the biomass and carbon content, four square inventory plots (20 m x $20 \mathrm{~m}$ ) were laid out in the $A$. costata and D. cochinchinensis plantations. Diameter at breast height (DBH) and total height were measured in each plot. The plantations were assessed in terms of survival, DBH and total height. The relationship between DBH and height was examined using linear regression analysis. For estimation of individual tree biomass, fives trees were randomly sampled from each $A$. costata and $D$. cochinchinensis plantations. Trees were felled as close as possible to the ground and the height of remaining stumps were about 0.10 m. Above-ground biomass was separated into different components (stem, branch, and leaf). Then the stem was cut into meter-long logs in order to measure the fresh weight of each stem. Fresh weights of the different tree components were determined using a weighting scale in the field. A $5 \mathrm{~cm}$ thick disc was cut from each of the meter long log and was weighed. About $500 \mathrm{~g}$ of bough and small branches, and $200 \mathrm{~g}$ of leaves were sampled. Stem samples were oven dried at $90^{\circ} \mathrm{C}$ for 72 hours, bough and small branches for 48 hours, and leaves for 24 to 36 hours (until constant weight or less than $15 \%$ moisture contents).

\section{Moisture content $(\%)=$ Sample fresh weight - Sample dry weight/Sample dry weight $x 100$}

The dry biomass values of all components were estimated from moisture contents of samples which were used to calculate carbon content of a tree. The carbon content default value of 0.46 (for DBH $<10 \mathrm{~cm}$ ) was used to estimate the carbon content of tree biomass while the root:shoot ratio default value of $20 \%$ of aboveground carbon was used as proposed by IPCC (2006). The relationship between DBH and tree biomass was constructed where the biomass was subsequently used to estimate the carbon storage in the six-year-old plantations.

Dry biomass of tree component $(\mathrm{kg})=$ sample dry weight/sample fresh weight $x$ total of fresh weight of tree component

Soil samples were collected at the centre of each sub-plot from different soil layers $(0-20 \mathrm{~cm}, 21-40 \mathrm{~cm}$ and $41-60 \mathrm{~cm})$ to analyze the soil organic carbon (SOC) and soil organic matter (SOM). SOC was obtained using the Walkey-Black (1934) method while the SOM was determined by multiplying \% SOC by 1.724 .

\section{Data analysis}

The mean values and standard errors of DBH, height, fresh weight, dry weight, \%SOM and \%SOC were analyzed using MS Excel 2007 and SAS 9.1.3 for Windows (SAS Institute Inc., USA). One-way analysis of variance (ANOVA) was used to test the differences between variances. Duncan's Multiple Range Test (DMRT) was used to examine the differences of among values. Significant differences for all values were determined at $\mathrm{p} \leq 0.05$.

\section{Results and Discussion}

\section{Growth performance of planted species}

The average DBH and heght of $A$. costata and D. cochinchinensis are shown in Table 1. The survival rate after six years of planting was higher in A. costata $(73.1 \%)$ with 813 trees ha- ${ }^{1}$ compared to $D$. cochinchinensis $(67.5 \%)$ with 750 tree/ha). The results also showed that linear regression equation for DBH and height was higher in D. cochinchinensis $\left(\mathrm{R}^{2}=0.77\right)$ than $A$. costata $\left(\mathrm{R}^{2}=0.51\right)$. While, the total basal area was shown higher in A. costata $(29.26$ $\mathrm{m}^{2}$ ha- $\left.^{-1}\right)$ than D. cochinchinensis $\left(22.21 \mathrm{~m}^{2}\right.$ ha- $\left.^{1}\right)$.

This may be explained by a slower growth rate in $D$. cochinchinensis (mean annual increment for DBH $0.63 \mathrm{~cm}$ year- ${ }^{1}$ and height 0.53 m year- ${ }^{1}$ ) compared to $A$. costata (mean annual increment for DBH $0.77 \mathrm{~cm}$ year- ${ }^{1}$ and height $0.61 \mathrm{~m}$ year-1) at the same age and site condition. Details of growth performance of some native plantation trials in Central part of Lao PDR were compiled in Table 2 ..

\section{Biomass and carbon content}

The total fresh biomass of $A$. costata and D. cochinchinensis were estimated at $10.63 \pm 2.37$ tha $^{-1}$ and $8.26 \pm 1.61$ tha $^{-1}$, respectively. The allocation of fresh biomass were significantly different in both species was found to be in the order of stem $(F=7.48, P=0.0522)>$ branch $(F=0.00, P=1.000)>\operatorname{root}(F=5.11, P=0.866)>\operatorname{leaf}(F=1.63$, $P=0.2711$ ) Figure $2 \mathrm{~A}$.

The total dry biomass of $A$. costata and D.cochinchinensis were then calculated from the moisture contents of sample component at $5.63 \pm 1.23$ t ha $^{1}{ }^{1}$ and $5.42 \pm 0.94$ t ha- $^{1}$, respectively. The allocation of dry biomass were also significantly different in both species were found to be in order of stem $(F=0.02, P=0.8912)>$ branch $(F=1.39, P=0.3038)>\operatorname{root}(F=0.26, P=0.6348)>$ leaf $(F=2.09$, $P=0.2222$ ) Figure $2 \mathrm{~B}$. While, shoot:root weight ratio in both species were 4.99 and 5.00 (fresh weight), 2.68 and 4.67 (biomass), and while 4.95 and 5.46 (carbon content) in D. cochinchinensis and $A$. costata.

Therefore, the estimated total C contents in A. costata and D. cochinchinensis were $2.59 \pm 0.56 \mathrm{t} \mathrm{ha}^{-1}$ and $2.50 \pm 0.43 \mathrm{t} \mathrm{ha}^{-1}$, respectively. The $\mathrm{C}$ contents in branches and leaves of $D$. cochinchinensis were slightly higher than (Table 3). Carbon contents in roots were insignificantly ( $p>0.05)$ different between the two species. On the other hand, the $\mathrm{C}$ content in stem was slightly higher in $A$. costata $1.31 \pm 0.31$ t ha- ${ }^{1}$ than $D$. cochinchinensis $1.19 \pm 0.18 \mathrm{t} \mathrm{ha}^{-1}(F=0.02, P=0.8854)$, branch $(F=1.30, P=0.3172)$, $\operatorname{root}(F=0.29, P=0.6205)$ and leaf $(F=1.19, P=0.2392)$. In this study, sample linear regression equation was used to determine the relationship among fresh weight, dry weight and carbon content of the two species (Figure 3 ). The best $\mathrm{R}^{2}$ values of 0.75 (AGB, BGB and carbon) and $\mathrm{R}^{2}=0.76$ value (total fresh weight) were obtained by $A$. costata and $D$. cochinchinensis, respectively (Table 4). However, the survival rate can affect the biomass and carbon contents (Thaung et al., 2007). According to Priaasukmana (1991) and Weidelt (1976) found that if weeding is carriout late, dipterocarps or deciduous species are easily damaged and also the importance of maintenance an insufficient tending is the most common reason for failure. There are only a few studies reported in the Asian region related to A. costata and D. cochinchinensis. Yamada et al. (2004) reported that 15-year-old D. cochinchinensis

How to Cite this Article: Chanhsamone Phongoudome, Don Koo Lee, Silavanh Sawathvong, Marilyn S. Combalicer, and Wai Mun Ho, et al,. "Biomass and Carbon Content Allocation of Six-year-old Anisoptera costata Korth. and Dalbergia cochinchinensis Pierre. Plantations in Lao PDR.,"Science Journal of Agricultural Research \& Management,Volume 2012, Article ID sjarm-259, 14 Pages, 2012. doi: 10.7237/sjarm/259 
in Thailand had a total biomass of $104 \mathrm{t} \mathrm{ha}^{-1}$ and root biomass of 28.8 tha- $^{-1}$. Most of the studies examined on aboveground biomass (AGB) (without detailed information on stem, bark, bough, branches, and leaves) or belowground biomass (BGB). In this study, data from some studies on native and exotic species in neighboring countries were summarized (Table 5). The productivity on biomass and $\mathrm{C}$ content more or less depends on species capacity, environment (temperature, soil nutrient, tree densities, rainfall, and wood density), human activities, and silvicultural practices in both plantation and natural forests (Baishya et al., 2009).

Moreover, biomass and $\mathrm{C}$ content are likely to increase according to the age of species in the same site (Yamada et al., 2004; Petsri et al., 2007). Other studies found that exotic species have higher ability than indigenous species to adapt in environments such as dry zone, poor soil, low rainfall (Min et al., 2006; Yamada et al., 2004). Phongoudome et al. (2011) reported that in two -year-old plantation with spacing $2 \mathrm{~m} \times 2 \mathrm{~m}$, two indigenous species such as Cassia siamea and Peltophorum dasyrachis were $(2.92 \pm 0.08$ and $1.99 \pm 0.07 \mathrm{~kg}$ tree $^{-1}$ ) more than total biomass and C content than Acacia mangium, A. auriculiformis and Eucalyptus camaldulensis $\left(1.96 \pm 0.12 ; 1.60 \pm 0.08\right.$ and $1.58 \pm 0.16 \mathrm{~kg}$ tree $\left.^{-1}\right)$, respectively.

The fresh biomass, dry biomass and $\mathrm{C}$ content of root, stem, branch and leaf increased with increasing of tree sizes (diameter) as well as sizes of the trees indicating that both species still produced and accumulated biomass for the next.

\section{Soil organic matter and soil organic carbon content}

Overall, total soil organic matter (SOM) and soil organic carbon (SOC) were low in both plantations according to soil standard $(<2.0$ low, 2.0-4.0 medium, and >4.0 high. However, SOM and SOC were higher in $D$. cochinchinensis $(1.164 \%$ and $0.675 \%$, respectively) than $A$. costata $(0.974 \%$ and $0.565 \%$, respectively). Both SOM and SOC were higher at $0-20 \mathrm{~cm}$ soil depth (Table 2) which was mostly attributed to the contribution of litter fall. The correlation between SOM and soil depth was high in A. costata and D. cochinchinensis plantations with $\mathrm{R}^{2}$ values of 0.99 and 0.94 , respectively. Similar relationship was also found in both plantations for SOC.

Montagnini and Porras (1998) and Krazenzel et al. (2003) reported similar condition where SOM and total nitrogen showed higher value at $0-15 \mathrm{~cm}$ of soil depth than other soil depths. According to Piotto et al. (2004), mixed plantations with native species would contribute much to sustainable management because they provide a greater range of goods and services than pure species plantations. Nevertheless, the amount of total C in soil natural forest tends to be higher than plantation (Takahashi et al., 2007).

\section{Conclusion}

This study examined the biomass of native plantation and their capacity to store carbon in trees and soils. The results showed that the six-year-old A. costata and D. cochinchinensis plantations are both comparable in terms of biomass accumulation and $\mathrm{C}$ sequestration. Based on the results of this study, the data obtained may be useful for forest management in Lao PDRs and could be shared among neighboring countries to restore degraded forest ecosystem in the future. Therefore, better silvicultural practices in natural forest and plantation as well as agroforestry are needed to increase biomass and carbon content in trees and soils. The results of this study suggest that through careful species selection and management practices based on understanding of natural succession and nutrient cycling processes, forest plantation could be a promising tool for tropical forest rehabilitation and carbon sequestration.

\section{Acknowledgements}

This study was supported by the ASEAN-Korea Environmental Cooperation Project (AKECOP) funded from Korea Ministry of Foreign Affair and Trade and Ministry of Environment. We would like to thank to the Lao Tree Seed Project/Danida Forest Seed Centre, Forest Research Centre, National Agriculture and Forestry Research Institute for allowing us to use their materials for this study.

\section{References}

1. Affendy H, Aminuddin M, Razak W, Arifin A, Mjiol AR (2009). Growth increments of indigenous species planted in secondary forest area. Research Journal of Forestry 3: 23-28.

2. Baishya R, Barik SK, Upadhaya K (2009). Distribution pattern of aboveground biomass in natural and plantation forests of humid tropics in northeast India. Tropical Ecology 50: 295-304.

3. Brown S (1997). Estimating biomass and biomass change of tropical forests: a prime. FAO Forestry Paper 134, FAO.

4. Department of Forestry (DoF) (2009). Annual Report 2008-2009. Vientiane, Laos. (un-published).

5. Dutca I, Abrudan IV, Blujdea V (2009). The impact of afforestation on carbon storage-a review. Bulletin of the Transilvania University of Brasov 2: 13-18.

6. FAO (2006). Global Forest Resources Assessment 2005. FAO Forestry Paper No. 147.

7. FAO (2010). Key findings Global Forest Resources Assessment. Rome, Italy. http://www.fao.org/forestry/fra2010 (2010. 5.14).

8. Francis JK (2000). Estimating biomass and carbon content of saplings in Puerto Rican secondary forests. Caribbean Journal of Science 36: 346-350.

9. Houghton RA, Goodale CL (2004). Effects of land use change on the carbon balance of terrestrial ecosystems. Global Change Biology 49: 243-253.

10. International Governmental Panel on Climate Change (IPCC) (2006). Guideline for national green-house gas inventory: agriculture, forestry and other land use (Volume 4). http://www.ipcc.nggip.iges.or.jp/public/gl/invs4.htm. (2010. 20.4).

11. Inthavongsa C, Phongsavanh S (2011). Growth performances of nine-year-old of Anisoptera costata and Dalbergia cochinchinnensis in Phonthong, Phonhong, Vientiane province, Lao PDR. A Bsc thesis, Faculty of Forestry, National University of Laos.

12. Kraenzel M, Castillo A, Moore T, Potvin C (2003). Carbon storage of harvest-age teak (Tectona grandis) plantation, Panama. Forest Ecology and Management 173: 213-225.

13. Losi CJ, Siccama TG, Condit R, Morales JE (2003). Analysis of alternative methods for estimating carbon stock in young tropical plantation. Forest Ecology and Management 184: 355-368.

14. Lugo AE, Brown S (1993). Management of tropical soils as sinks or sources of atmospheric carbon. Plant and Soil 149: 27-41.

15. Min ZO, Shin T, Oosumi Y, Kiyono Y (2006). Biomass of planted forests and biotic climax of shrub and grass communities in the central dry zone of Myanmar. Bulletin of FFPRI 5: 271-288.

16. Ministry of Agriculture and Forestry (MAF) (2005). Forestry Strategy to the year 2020. Vientiane, Lao PDR.

17. Montagnini F, Porras C (1998). Evaluating the role of plantations as carbon sinks: an example of integrative approach from the humid tropics. Environment Management 22: 459-470.

How to Cite this Article: Chanhsamone Phongoudome, Don Koo Lee, Silavanh Sawathvong, Marilyn S. Combalicer, and Wai Mun Ho, et al,. "Biomass and Carbon 
18. Parrotta JA (1992). The role of plantation forests in rehabilitating degraded tropical ecosystems. Agriculture Ecosystem and Environment 41: 115-133.

19. Petsri S, Pumijumnong N, Wachrinrat C, Thoranisom S (2007). Aboveground carbon content in mixed deciduous forest and teak plantations. Environment and Natural Resources 5: 1-10.

20. Phengdouang V, Khamphanh K, Phengsengchanh K, Ramangkoun B, Lengsouthiphong P, Wallin M (1994). Growth rate of planted Local tree species in Central Lao PDR. Silviculture Division, Department of Forestry, Lao PDR.

21. Phongoudome $\mathrm{C}$, Phongdalath $\mathrm{S}$, Boulom $\mathrm{C}$, Nidtavong $\mathrm{V}$, Inthavongsa I (2011). Preliminary results of biomass and carbon content in two-year-old plantation in Forestry Research Centre, Namsouang, Naxaithong, Vientiane Capital, Central part of Lao PDR. Annual Research Report 2010-2011.

22. Piotto D, Viquez E, Montagnini F, Kanninen M (2004). Pure and mixed forest plantations with native species of the dry tropics of Costa Rica: a comparison of growth and productivity. Forest Ecology and Management 190: 359-372.

23. Priasukmana S (1991). Planting experiments of dipterocarps in Est Kalimantan. In: I Soerianegara, S.S. Tjitrosomo, R. C. Umaly and I. Umboh (Eds). Proc. Of 4th Roun-Table Conferences on Dipterocarps, Biotrop Special Publication. No. 41, Bogor, Indonesia, pp.417-423.

24. Singh P, Lodhiyal LS (2009). Biomass and carbon allocation in 8-year-old Poplar (Populus deltoids Marsh) plantation in Tarai agroforestry systems of central Himalaya, India. New York Science Journal 2: 49-53.

25. Takahashi M, Limtong P, Suksawang S, Hirai K (2007). A comparison of the carbon balance in the soil between a natural forest and a young teak plantation. http://citeseer.ist.psu.edu/cache/papers/cs/31109/http://zSzzSw ww.sfst.orgzSzProceedingszSzl7WCSS_CDzSzpaperSz0350.pdf/sym posium-no-paper-no.pdf (2010. 4. 20)

26. Thaung NO, Lee DK, Combalicer MS (2007). Carbon sequestration of teak (Tectona grandis Linn.f.) plantation in the Bago Yoma region of Myanmar. Journal Korean Forest Society 96: 602-608.
27. Walkley A, Black IA (1934). An examination of Degtjareff method for determining soil organic matter and a proposed modification of the chromic acid titration method. Soil Science 37:29-37.

28. Weidelt HJ (1976). Improvement of overlogged areas by enrichment planting. In: Weidelt HJ (Ed). Manual of reforestation and erosion control for the Philippines. GTZ, Eschborn, Germany, pp. 130-135.

29. Yamada M, Toma T, Hiratsuka M, Morikawa Y (2004). Biomass and potential nutrient removal by harvesting in short-rotation plantations. pp. 213-226. In: Nambiar EKS, Ranger J, Tiarks A, Toma T (Eds) Proceedings of workshops in Congo July 2001 and China 2003 Site management and productivity in tropical plantation forests. CIFOR.
Figure 1. The location of the study site in Lao PDR

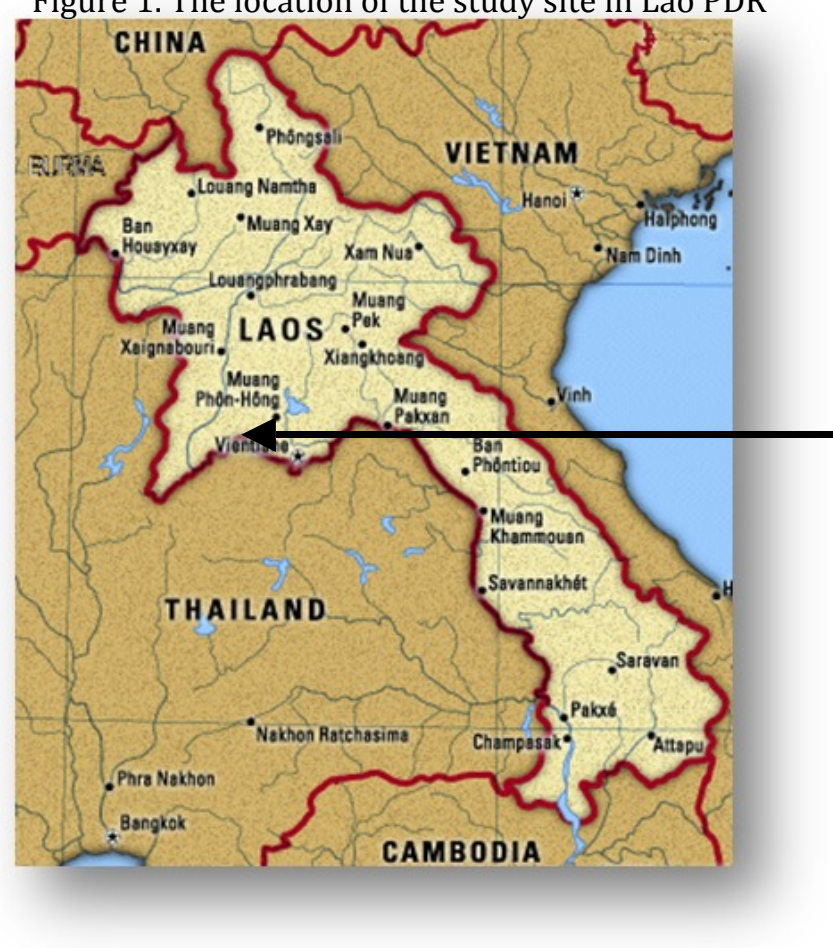

\section{Plantation}

How to Cite this Article: Chanhsamone Phongoudome, Don Koo Lee, Silavanh Sawathvong, Marilyn S. Combalicer, and Wai Mun Ho, et al,. "Biomass and Carbon Content Allocation of Six-year-old Anisoptera costata Korth. and Dalbergia cochinchinensis Pierre. Plantations in Lao PDR.,"Science Journal of Agricultural Research \& Management,Volume 2012, Article ID sjarm-259, 14 Pages, 2012. doi: 10.7237/sjarm/259 
Figure 2. Fresh biomass, dry biomass and carbon content allocation in six-year-old plantation

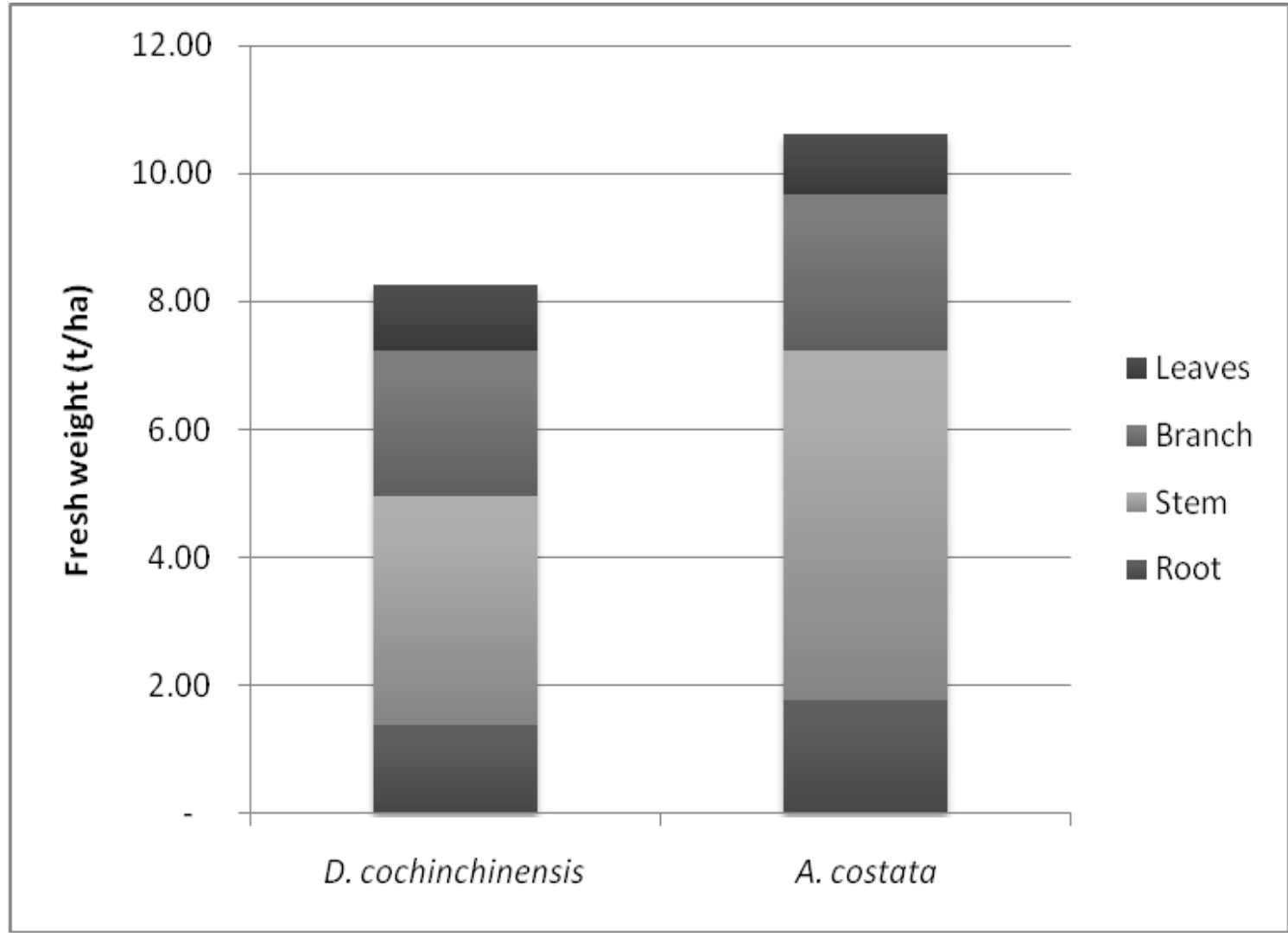

(A) fresh biomass (t ha-1)

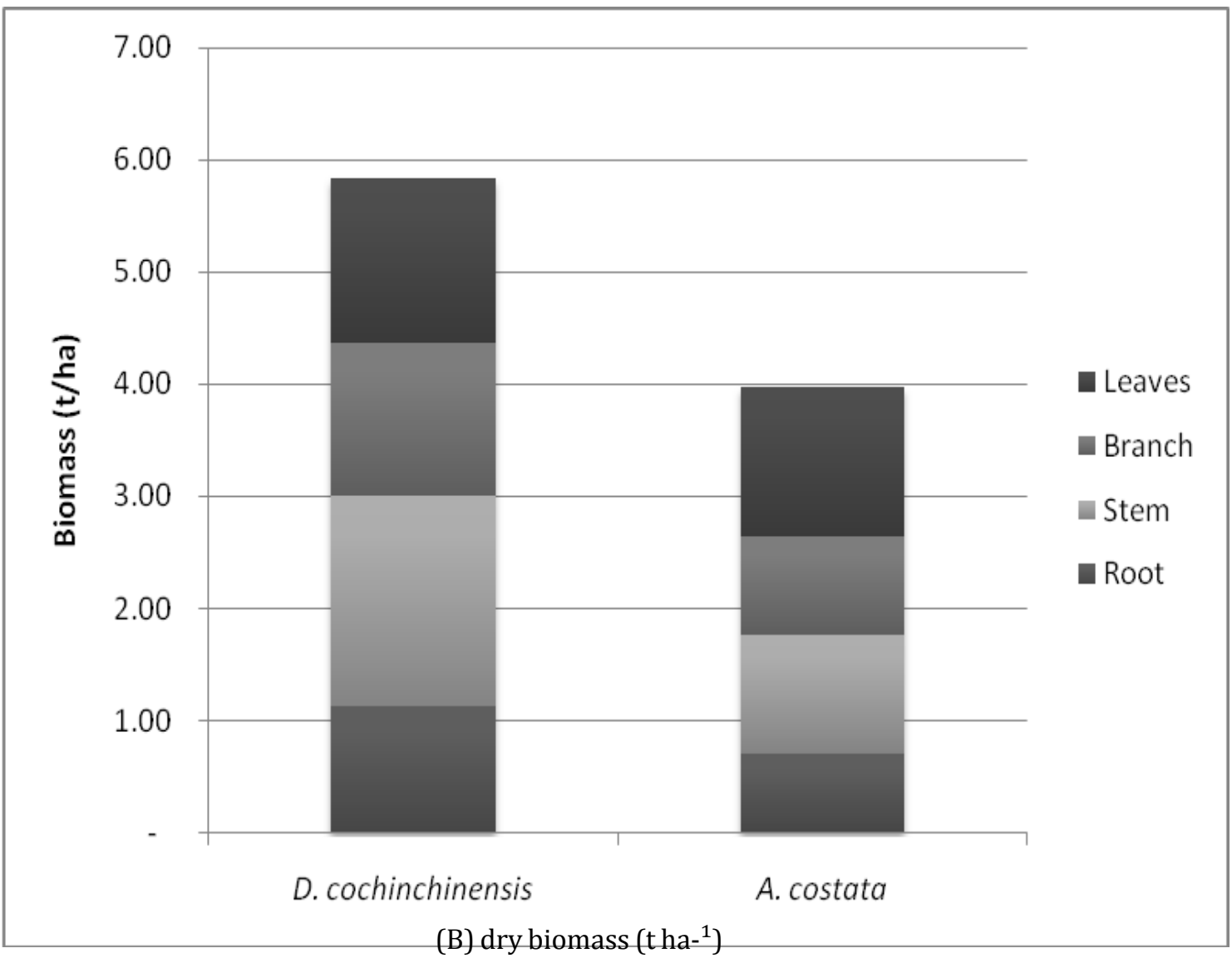

How to Cite this Article: Chanhsamone Phongoudome, Don Koo Lee, Silavanh Sawathvong, Marilyn S. Combalicer, and Wai Mun Ho, et al, "Biomass and Carbon Content Allocation of Six-year-old Anisoptera costata Korth. and Dalbergia cochinchinensis Pierre. Plantations in Lao PDR.,"Science Journal of Agricultural Research \& Management,Volume 2012, Article ID sjarm-259, 14 Pages, 2012. doi: 10.7237/sjarm/259 


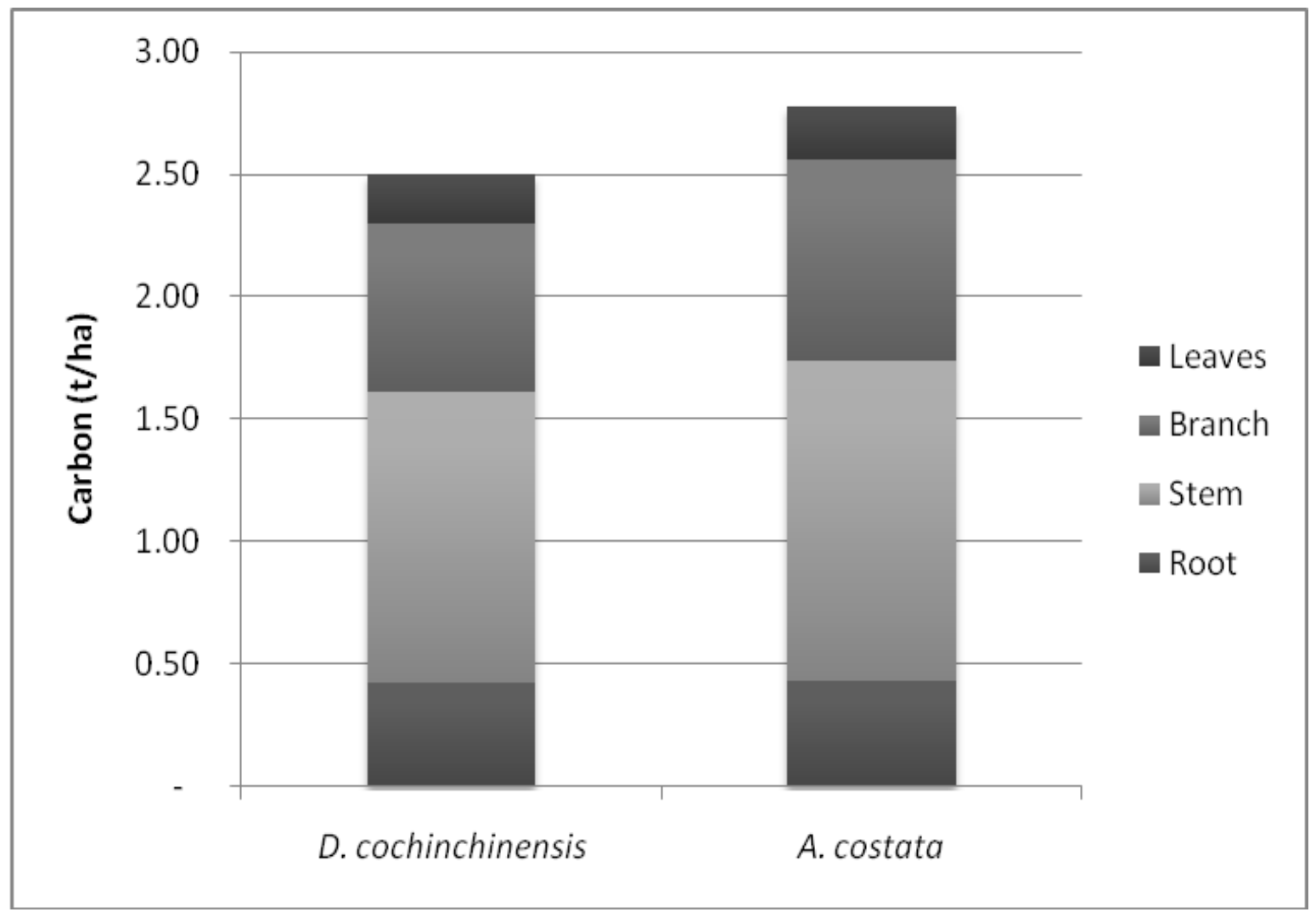

(C) carbon content $\left(\mathrm{t} \mathrm{ha}^{-1}\right)$

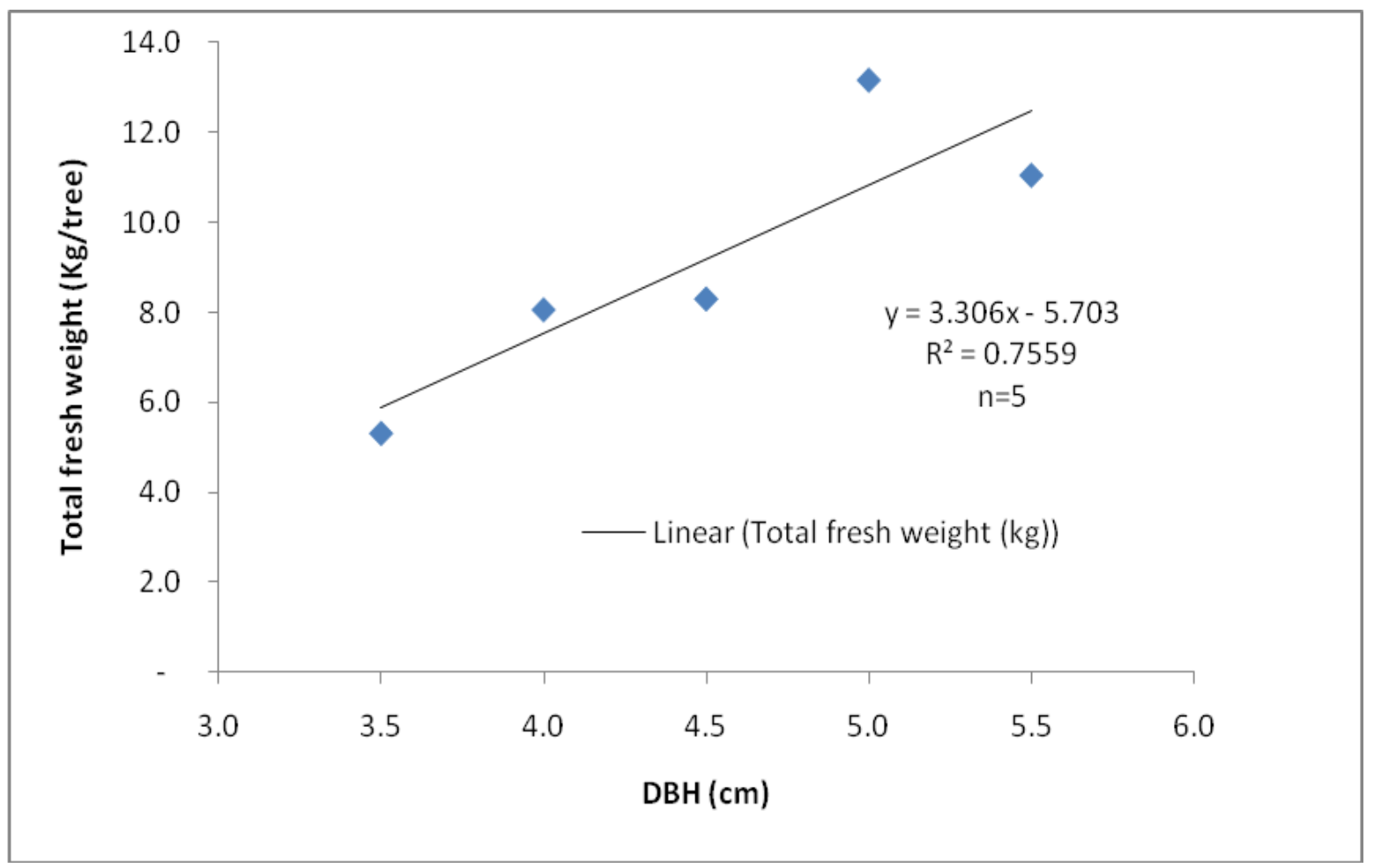

(A) Dalbergia cochinchinensis (total fresh biomass)

How to Cite this Article: Chanhsamone Phongoudome, Don Koo Lee, Silavanh Sawathvong, Marilyn S. Combalicer, and Wai Mun Ho, et al,. "Biomass and Carbon Content Allocation of Six-year-old Anisoptera costata Korth. and Dalbergia cochinchinensis Pierre. Plantations in Lao PDR.,"Science Journal of Agricultural Research \& 


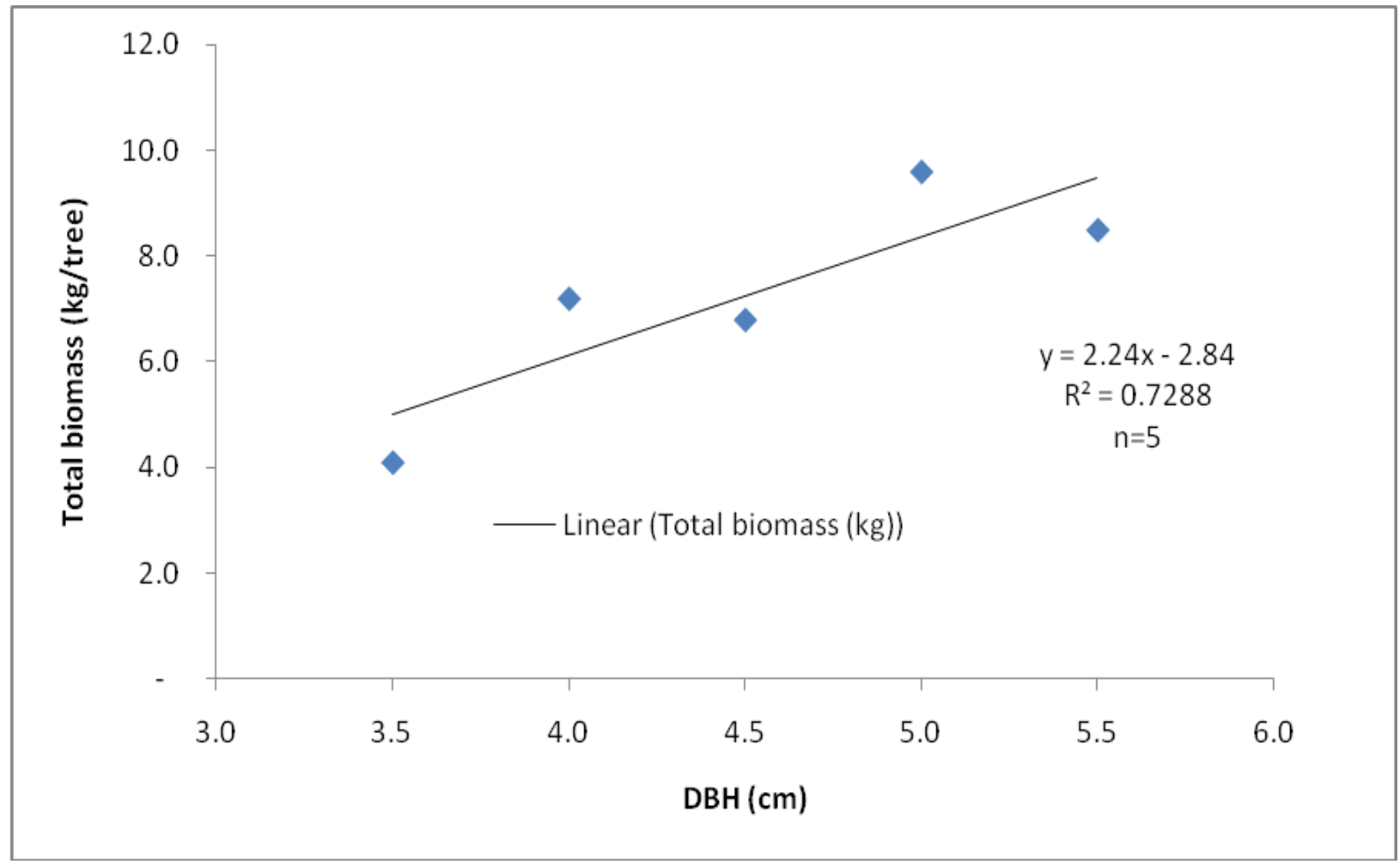

(B) Dalbergia cochinchinensis (total dry biomass)

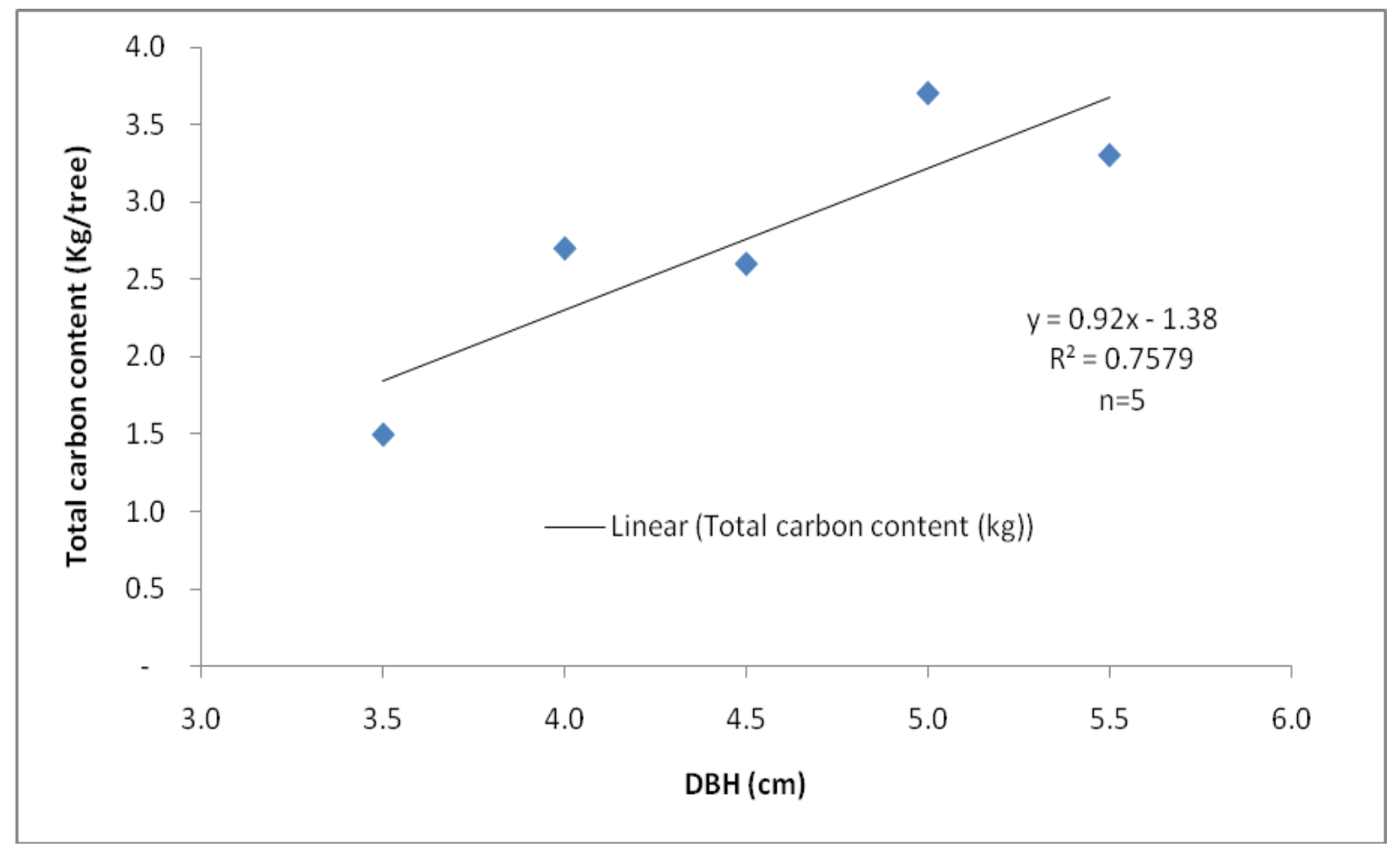

(C) Dalbergia cochinchinensis (total carbon content) 


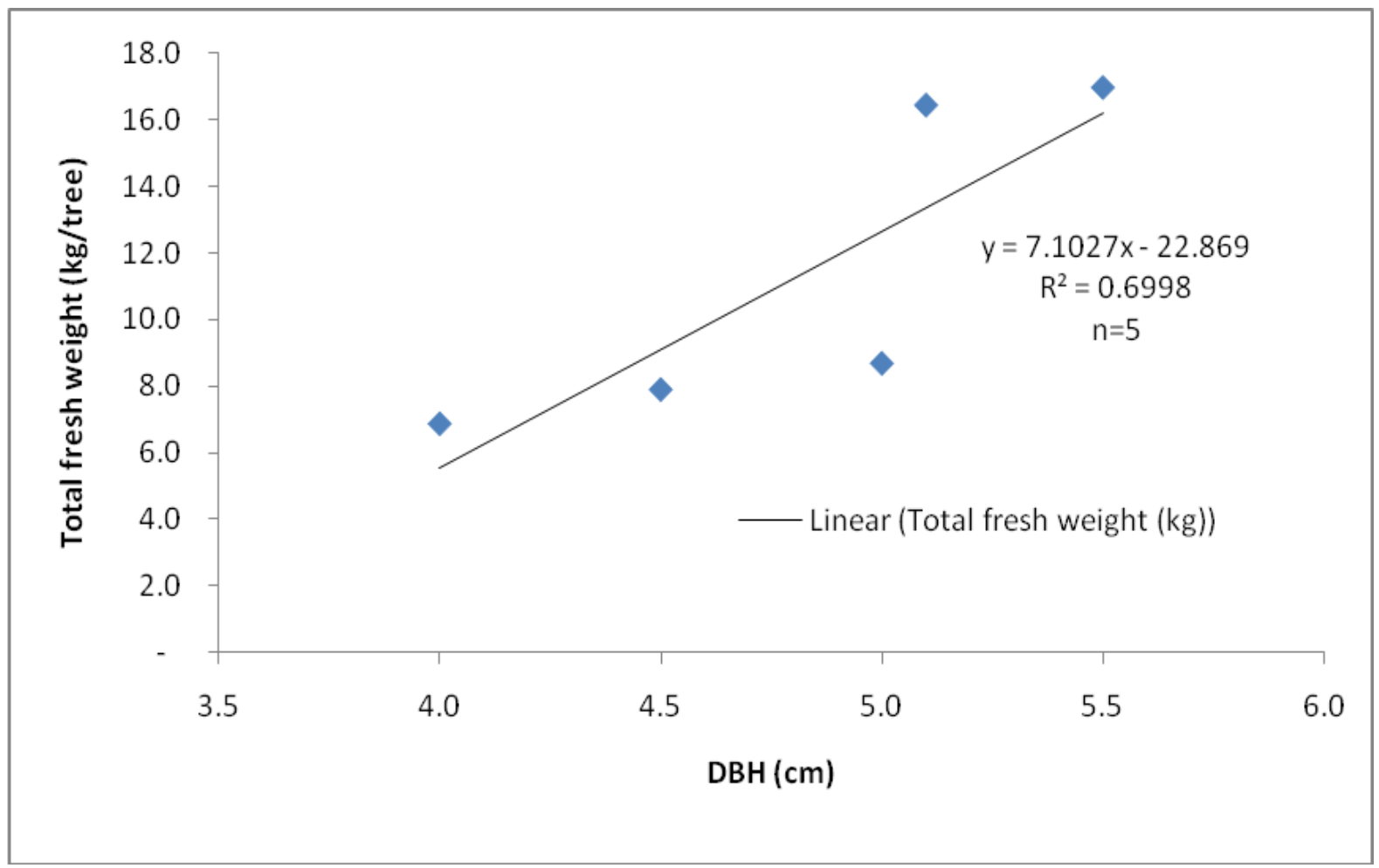

(D) Anisoptera costata (total fresh biomass)

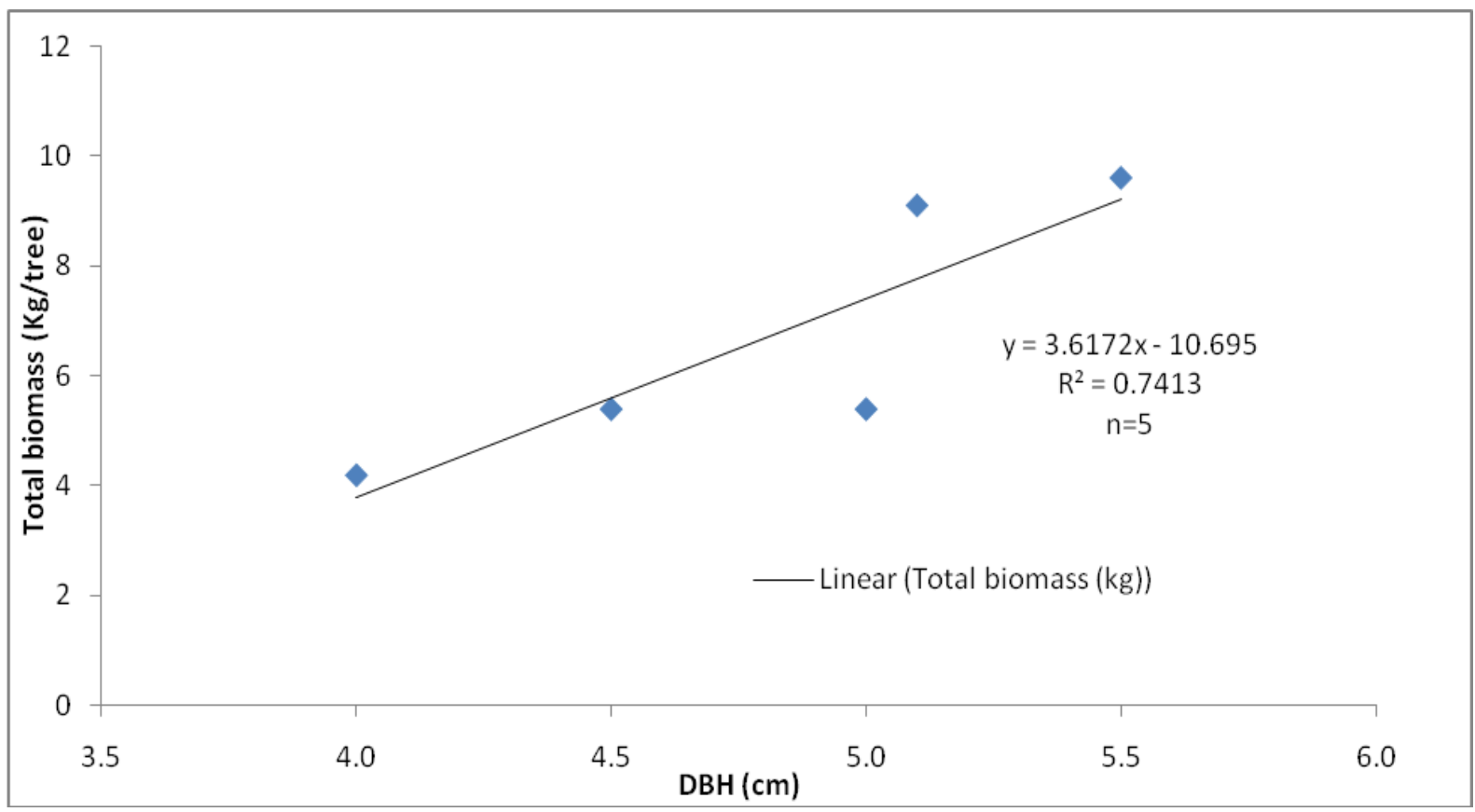

(E) Anisoptera costata (total dry biomass) 


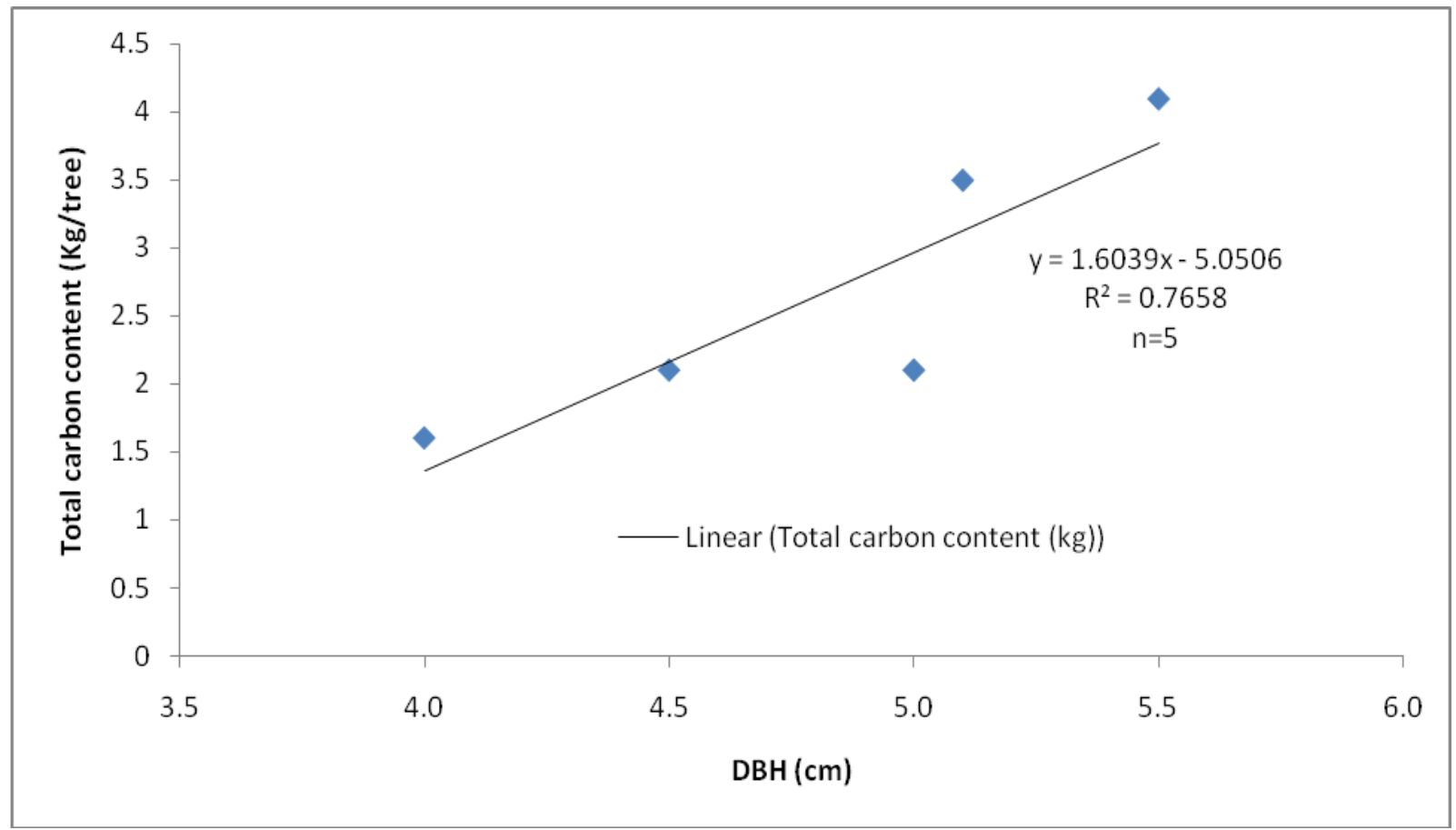

(F) Anisoptera costata (total carbon content)

Figure 4. Soil organic matter and soil organic carbon content in six-year-old plantation

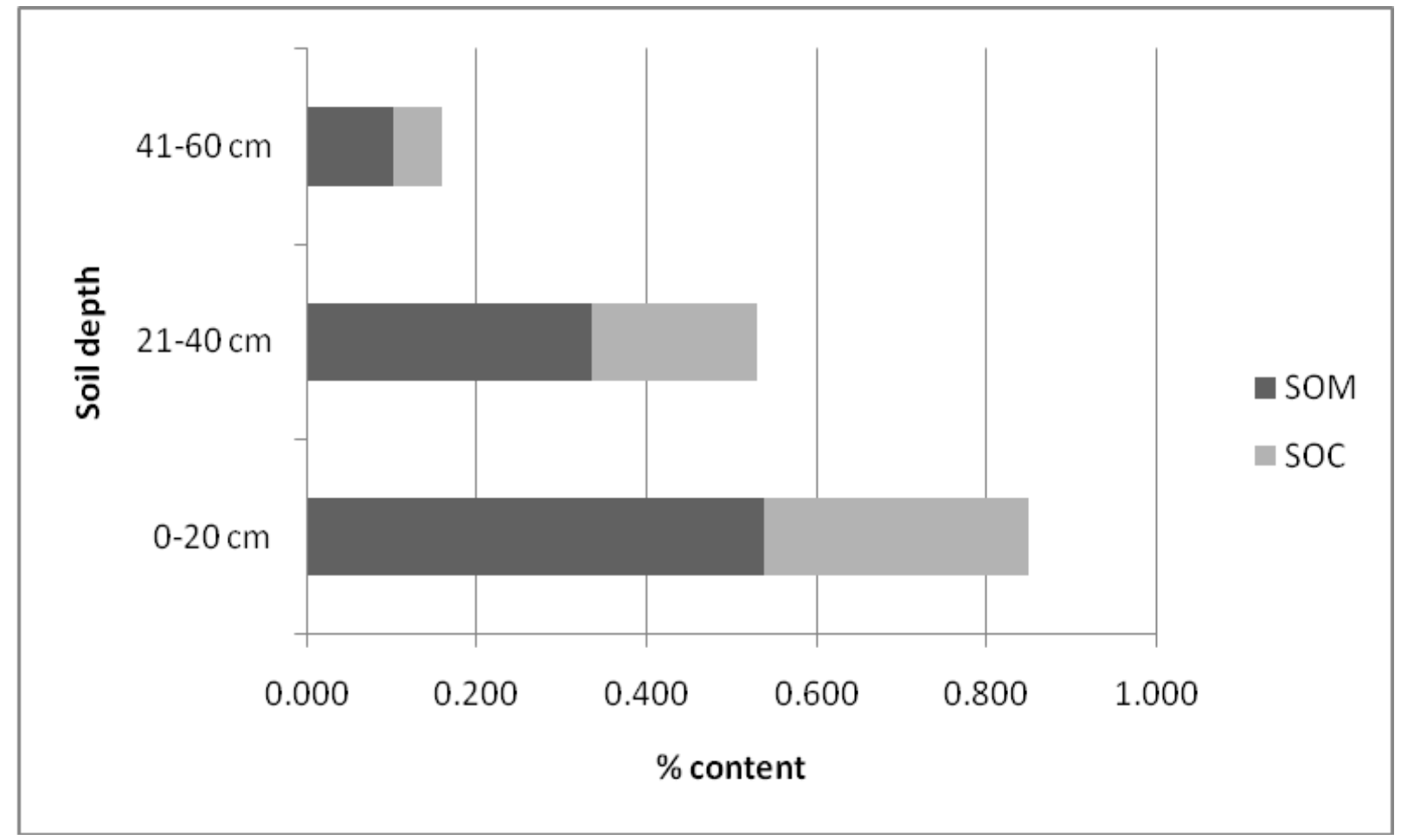

(A) Dalbergia cochinchinensis

How to Cite this Article: Chanhsamone Phongoudome, Don Koo Lee, Silavanh Sawathvong, Marilyn S. Combalicer, and Wai Mun Ho, et al,. "Biomass and Carbon Content Allocation of Six-year-old Anisoptera costata Korth. and Dalbergia cochinchinensis Pierre. Plantations in Lao PDR.," Science Journal of Agricultural Research \& 


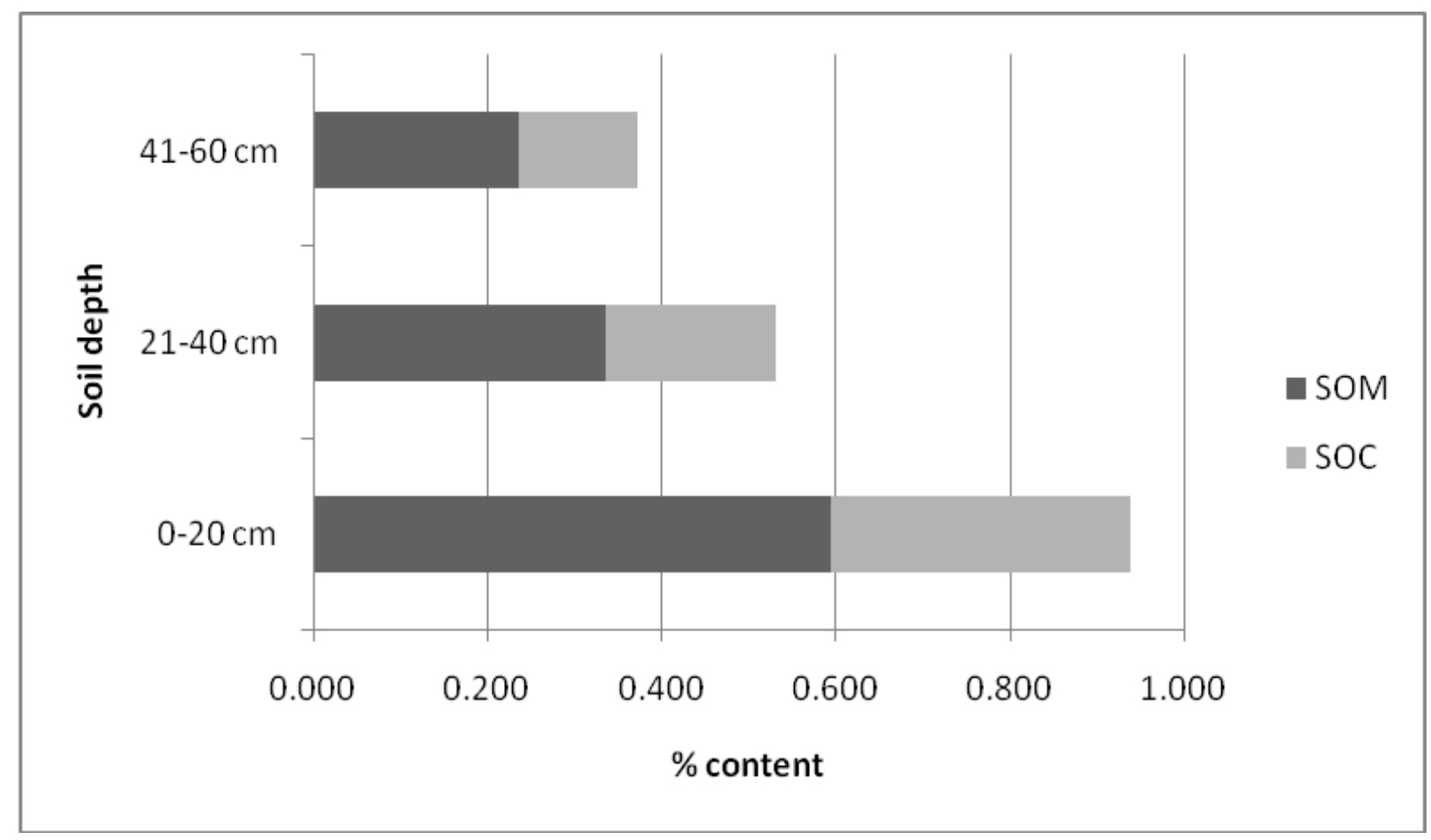

(B) Anisoptera costata

Table 1. Density, survival rate, diameter at breast height (DBH), height $(\mathrm{H})$ and basal area of six-year-old plantations of Anisoptera costata and Dalbergia cochinchinensis.

\begin{tabular}{|c|c|c|c|c|c|}
\hline Species & Density & \multicolumn{1}{|c|}{ Survival } & DBH & H & Basal area \\
\hline & (tree/ha-1) & rate (\%) & $(\mathrm{cm})$ & $(\mathrm{m})$ & $\left(\mathrm{m}^{2}\right.$ ha- $\left.^{-1}\right)$ \\
\hline A. costata & 813 & $73.1 \mathrm{a}$ & $4.59 \pm 0.17 \mathrm{a}$ & $3.60 \pm 0.08 \mathrm{a}$ & $29.26 \mathrm{a}$ \\
\hline $\begin{array}{c}\text { D. } \\
\text { cochinchinensis }\end{array}$ & 750 & $67.5 \mathrm{~b}$ & $3.77 \pm 0.18 \mathrm{~b}$ & $3.18 \pm 0.13 \mathrm{~b}$ & $22.21 \mathrm{~b}$ \\
\hline
\end{tabular}

Note: Values with different letters denote significant differences according to DMRT at $(\mathrm{p}<0.05)$ 
Table 2. Comparisons of growth performance of related two native planted species in Central Part of Lao PDR.

\begin{tabular}{|c|c|c|c|c|c|c|c|c|}
\hline Species & Age & Spacing & Location & DBH (cm) & MAI of DBH & Height (m) & MAI height & References \\
\hline $\begin{array}{l}\text { Dalbergia } \\
\text { cochinchine } \\
\text { nsis }\end{array}$ & 6 & $3 \times 3$ & Namsouang & 3.6 & 0.6 & 3.2 & 0.53 & This study \\
\hline $\begin{array}{c}\text { Dalbergia } \\
\text { cochinchine } \\
\text { nsis }\end{array}$ & 9 & $3 \times 3$ & Phonthong & 6.45 & 0.71 & 8.1 & 0.90 & $\begin{array}{l}\text { Inthavongsa } \\
\text { and } \\
\text { Phongsav } \\
\text { anh } 2011\end{array}$ \\
\hline $\begin{array}{l}\text { Dalbergia } \\
\text { cochinchine } \\
\text { nsis }\end{array}$ & 9 & $3 \times 3$ & Namsouang & 11.5 & 1.28 & 14.1 & 1.56 & $\begin{array}{l}\text { Phengdou } \\
\text { ang et al. } \\
1994\end{array}$ \\
\hline $\begin{array}{l}\text { Dalbergia } \\
\text { cochinchine } \\
\text { nsis }\end{array}$ & 11 & $3 \times 3$ & Namsouang & 11.4 & 1.04 & 14.6 & 1.33 & $\begin{array}{l}\text { Phengdou } \\
\text { ang et al. } \\
1994\end{array}$ \\
\hline $\begin{array}{l}\text { Dalbergia } \\
\text { cochinchine } \\
\text { nsis }\end{array}$ & 20 & $3 \times 3$ & $\begin{array}{l}\text { Savanhnak } \\
\text { het }\end{array}$ & 18.5 & 0.92 & $19 \cdot 0$ & 0.95 & $\begin{array}{l}\text { Phengdou } \\
\text { ang et al. } \\
1994\end{array}$ \\
\hline $\begin{array}{l}\text { Dalbergia } \\
\text { cochinchine } \\
\text { nsis }\end{array}$ & 20 & $3 \times 3$ & $\begin{array}{l}\text { Savanhnak } \\
\text { het }\end{array}$ & 21.8 & 1.09 & $17 \cdot 0$ & 0.85 & $\begin{array}{l}\text { Phengdou } \\
\text { ang et al. } \\
1994\end{array}$ \\
\hline $\begin{array}{l}\text { Dalbergia } \\
\text { cochinchine } \\
\text { nsis }\end{array}$ & 20 & $3 \times 3$ & Namsouang & 15.5 & 0.77 & $13 \cdot 0$ & 0.65 & $\begin{array}{l}\text { Phongoud } \\
\text { ome et al. } \\
2011\end{array}$ \\
\hline $\begin{array}{l}\text { Dalbergia } \\
\text { cochinchine } \\
\text { nsis }\end{array}$ & 20 & $3 \times 3$ & Namsouang & 16.5 & 0.83 & 14.3 & 0.72 & $\begin{array}{l}\text { Phongoud } \\
\text { ome et al } \\
2011\end{array}$ \\
\hline $\begin{array}{l}\text { Dalbergia } \\
\text { cochinchine } \\
\text { nsis }\end{array}$ & 27 & $3 \times 3$ & Namsouang & 20.6 & 0.76 & 18.5 & 0.68 & $\begin{array}{l}\text { Phongoud } \\
\text { ome et al } \\
2011\end{array}$ \\
\hline $\begin{array}{l}\text { Anisoptera } \\
\text { costata }\end{array}$ & 6 & $3 \times 3$ & Namsouang & 4.6 & 0.77 & $3 \cdot 80$ & 0.63 & This study \\
\hline $\begin{array}{l}\text { Anisoptera } \\
\text { costata }\end{array}$ & 9 & $3 \times 3$. & Phonthong & 5.68 & 0.63 & 5.47 & 0.61 & $\begin{array}{l}\text { Inthavongsa } \\
\text { and } \\
\text { Phongsav } \\
\text { anh } 2011\end{array}$ \\
\hline
\end{tabular}


Table 3. Total carbon contents in trees components and soil of six-year-old plantations of Anisoptera costata and Dalbergia cochinchinensis.

\begin{tabular}{|c|c|c|c|c|c|c|c|c|c|c|c|c|c|}
\hline \multicolumn{14}{|l|}{$\begin{array}{c}\text { Specie } \\
\mathbf{S}\end{array}$} \\
\hline & Stem & Branch & Leaves & Root & Total & $\begin{array}{c}0-20 \\
\mathrm{~cm}\end{array}$ & $\begin{array}{c}21-40 \\
\mathrm{~cm}\end{array}$ & $\begin{array}{c}41-60 \\
\mathrm{~cm}\end{array}$ & Total & $\begin{array}{c}0-20 \\
\mathrm{~cm}\end{array}$ & $\begin{array}{c}21-40 \\
\mathrm{~cm}\end{array}$ & $\begin{array}{c}41-60 \\
\mathrm{~cm}\end{array}$ & Total \\
\hline $\begin{array}{c}\text { A. } \\
\text { costata }\end{array}$ & 1.31 & 0.66 & 0.18 & 0.43 & 2.58 & 0.583 & 0.336 & 0.101 & 0.974 & 0.312 & 0.195 & 0.058 & 0.565 \\
\hline & $\pm 0.27 \mathrm{a}$ & & & & & & & & & & & & \\
\hline $\begin{array}{c}\mathrm{D} . \\
\text { cochin } \\
\text { chinen } \\
\text { sis }\end{array}$ & 1.19 & 0.69 & $0 \cdot 20$ & 0.42 & $2 \cdot 50$ & 0.594 & 0.336 & 0.235 & 1.164 & 0.344 & 0.195 & 0.136 & 0.675 \\
\hline & $\pm 0.18 \mathrm{~b}$ & & & & & & & & & & & & \\
\hline
\end{tabular}

Note: Values with different letters denote significant differences according to DMRT at $(\mathrm{p}<0.05)$

Table 4. Parameter values and simple linear regression statistics analysis $\{\log Y=a+b \log X\}$; where: $Y=$ total fresh weight/AGB $/ \mathrm{BGB} /$ carbon content $(\mathrm{kg})$ and $\mathrm{X}=(\mathrm{DBH}) 2 \mathrm{x}$ height $\}$

\begin{tabular}{|c|c|c|c|c|c|c|}
\hline Species & Parameter (Y) & a & b & R2 & S.E. & Prob. level \\
\hline A. costata & Fresh weight & 7.103 & -22.869 & $0 \cdot 70$ & 2.37 & $<0.05$ \\
\hline & AGB & 3.491 & -10.654 & $0 \cdot 75$ & 1.03 & $<0.05$ \\
\hline & BGB & 0.682 & -2.131 & $0 \cdot 75$ & 0.2 & $<0.05$ \\
\hline & Carbon & 1.568 & -4.901 & $0 \cdot 75$ & 0.45 & $<0.05$ \\
\hline $\begin{array}{c}\text { D. } \\
\text { cochinchinen } \\
\text { sis }\end{array}$ & Fresh weight & 3.306 & -5.703 & $0 \cdot 76$ & 1.61 & $<0.05$ \\
\hline & AGB & $1 \cdot 890$ & -2.485 & $0 \cdot 74$ & 0.85 & $<0.05$ \\
\hline & BGB & 0.037 & -0.497 & $0 \cdot 74$ & 0.16 & $<0.05$ \\
\hline & Carbon & 0.869 & -1.143 & $0 \cdot 74$ & 0.32 & $<0.05$ \\
\hline
\end{tabular}


Table 5. Comparison of biomass allocation of some native and exotic species in selected (neighboring countries of Lao PDR)

\begin{tabular}{|c|c|c|c|c|c|c|c|c|c|}
\hline Species & Site & Age & Stem & Bark & $\begin{array}{c}\text { AGB (t } \\
\text { ha-1) } \\
\text { Branch }\end{array}$ & Leaf & Root & Total & Source \\
\hline $\begin{array}{l}\text { Acacia } \\
\text { auriculifo } \\
\text { rmis }\end{array}$ & $\begin{array}{l}\text { Songbe, } \\
\text { Vietnam }\end{array}$ & 6 & 67.8 & 10.1 & 12.6 & 5.3 & 19.5 & $117 \cdot 0$ & $\begin{array}{l}\text { Yamada et } \\
\text { al. } 2004\end{array}$ \\
\hline $\begin{array}{l}\text { Acacia } \\
\text { auriculifo } \\
\text { rmis }\end{array}$ & $\begin{array}{l}\text { Vung Tau, } \\
\text { Vietnam }\end{array}$ & 7 & 92.8 & $18 \cdot 0$ & 20.2 & 5.1 & 15.6 & 136.1 & $\begin{array}{l}\text { Yamada et } \\
\text { al. } 2004\end{array}$ \\
\hline $\begin{array}{l}\text { AcaAcacia } \\
\text { mangium } \\
\text { cia } \\
\text { mangium }\end{array}$ & \begin{tabular}{|l} 
Song Be, \\
Vietnam
\end{tabular} & 6 & 92.5 & 15.5 & 9.8 & 3.3 & 24.2 & 145.4 & $\begin{array}{l}\text { Yamada et } \\
\text { al. } 2004\end{array}$ \\
\hline $\begin{array}{l}\text { Eucalyp } \\
\text { tus } \\
\text { camaldule } \\
\text { nsis }\end{array}$ & $\begin{array}{l}\text { Sakaerat, } \\
\text { Thailand }\end{array}$ & 15 & 67.1 & 12.4 & 13.7 & 1.5 & 18.9 & 113.6 & $\begin{array}{l}\text { Yamada et } \\
\text { al. } 2004\end{array}$ \\
\hline $\begin{array}{l}\text { Dalbergia } \\
\text { cochinchi } \\
\text { nensis }\end{array}$ & $\begin{array}{l}\text { Sakaerat, } \\
\text { Thailand }\end{array}$ & 15 & 73.5 & 10.1 & 17.1 & 3.4 & 28.8 & $104 \cdot 0$ & $\begin{array}{l}\text { Yamada et } \\
\text { al. } 2004\end{array}$ \\
\hline $\begin{array}{l}\text { Tectona } \\
\text { grandis }\end{array}$ & $\begin{array}{l}\text { Bago } \\
\text { Yoma, } \\
\text { Myanmar }\end{array}$ & 6 & $18 \cdot 0$ & 5.3 & 3.9 & 2.2 & 6.6 & $36.0 * *$ & $\begin{array}{l}\text { Thaung et } \\
\text { al. } 2007\end{array}$ \\
\hline $\begin{array}{l}\text { Eucalyp } \\
\text { tus } \\
\text { camaldule } \\
\text { nsis }\end{array}$ & $\begin{array}{l}\text { Central } \\
\text { Dry zone, } \\
\text { Myanmar }\end{array}$ & $6-11$ & - & - & - & - & - & 14.83 & $\begin{array}{l}\text { Min et al. } \\
2006\end{array}$ \\
\hline $\begin{array}{l}\text { Acacia } \\
\text { catechu }\end{array}$ & $\begin{array}{l}\text { Central } \\
\text { Dry zone, } \\
\text { Myanmar }\end{array}$ & 7 & - & - & - & - & - & 10.62 & $\begin{array}{l}\text { Min et al. } \\
2006\end{array}$ \\
\hline $\begin{array}{l}\text { Tectona } \\
\text { grandis }\end{array}$ & $\begin{array}{l}\text { Lansak, } \\
\text { Uthaith } \\
\text { ani, } \\
\text { Thailand }\end{array}$ & 1 & 10.72 & - & - & - & - & 10.72 & $\begin{array}{l}\text { Petsri et } \\
\text { al. } 2007\end{array}$ \\
\hline $\begin{array}{l}\text { Tectona } \\
\text { grandis }\end{array}$ & $\begin{array}{l}\text { Lansak, } \\
\text { Uthaith } \\
\text { ani, } \\
\text { Thailand }\end{array}$ & 5 & 27.64 & - & - & - & - & 27.64 & $\begin{array}{l}\text { Petsri et } \\
\text { al. } 2007\end{array}$ \\
\hline
\end{tabular}




\begin{tabular}{|c|c|c|c|c|c|c|c|c|c|}
\hline $\begin{array}{l}\text { Tectona } \\
\text { grandis }\end{array}$ & $\begin{array}{l}\text { Lansak, } \\
\text { Uthaith } \\
\text { ani, } \\
\text { Thailand }\end{array}$ & 7 & 59.52 & - & - & - & - & 59.52 & $\begin{array}{l}\text { Petsri et } \\
\text { al. } 2007\end{array}$ \\
\hline $\begin{array}{l}\text { Tectona } \\
\text { grandis }\end{array}$ & $\begin{array}{l}\text { Lansak, } \\
\text { Uthaith } \\
\text { ani, } \\
\text { Thailand }\end{array}$ & 10 & 67.68 & - & - & - & - & 67.68 & $\begin{array}{l}\text { Petsri et } \\
\text { al. } 2007\end{array}$ \\
\hline $\begin{array}{l}\text { Tectona } \\
\text { grandis }\end{array}$ & $\begin{array}{l}\text { Lansak, } \\
\text { Uthaith } \\
\text { ani, } \\
\text { Thailand }\end{array}$ & 15 & 58.76 & - & - & - & - & 58.76 & $\begin{array}{l}\text { Petsri et } \\
\text { al. } 2007\end{array}$ \\
\hline $\begin{array}{c}\text { Dalbergia } \\
\text { cochinchi } \\
\text { nensis }\end{array}$ & $\begin{array}{c}\text { Naxaith } \\
\text { ong, } \\
\text { Vientiane, } \\
\text { Laos }\end{array}$ & 6 & $2.59 *$ & $*$ & 1.49 & 0.43 & 0.9 & 5.42 & This study \\
\hline $\begin{array}{c}\text { Anisopt } \\
\text { era } \\
\text { costata }\end{array}$ & $\begin{array}{l}\text { Naxaith } \\
\text { ong, } \\
\text { Vientiane, } \\
\text { Laos }\end{array}$ & 6 & $2.86^{*}$ & $*$ & 1.44 & 0.39 & 0.94 & 5.63 & This study \\
\hline
\end{tabular}

Notes: * bark, branches, and leaves are combined with stem as AGB, $(-)$ data not available, $\left({ }^{* *}\right)$ recalculate 